\title{
FORUM
}

Submitted 01.26.2017. Approved 03.06.2017

Evaluated by double-blind review process. Scientific Editors: Marlei Pozzebon, Eduardo Henrique Diniz, Nathalie Mitev, François-Xavier de Vaujany, Miguel Pina e Cunha, and Bernard Leca

DOI: http://dx.doi.org/10.1590/S0034-759020170603

\section{BUILDING COLLABORATION? CO-LOCATION AND “DIS-LOCATION" IN A RAILWAY CONTROL POST}

\author{
Construindo uma colaboração? Da co-locação à des-locação em um centro de \\ controle ferroviário
}

\author{
¿Construyendo colaboración? De co-locación a "des-plazamiento" en un centro \\ de control ferroviario
}

\begin{abstract}
This paper studies the design of co-located spaces and how organizational actors experience such spaces. The literature on co-location is ambiguous about how reduced physical distance increases collaboration. To address this problem, we draw on an ethnographic study of a co-located railway control center, housing the largest Dutch railway organizations under one roof. Although the intention of the co-location was to improve collaboration by bringing different organizations into closer proximity, our findings tell a different story. Railway employees developed several territorial practices (preserving existing boundaries, creating new boundaries, and the situational use of boundaries) through which they resisted the design of the control center, thereby changing the control center from co-located to "dis-located." We argue that understanding the relationship between co-location and collaboration should not only focus on how such spaces are designed but, rather, account for how spaces where collaboration is demanded are experienced and used by employees.
\end{abstract}

KEYWORDS | Organizational space, territoriality, collaboration, co-location, inter-organizational.

\section{RESUMO}

Este artigo estuda o desenho de espaços co-localizados e como os atores organizacionais experimentam esses espaços. A literatura sobre edifícios co-localizados é ambígua em explicar como e se uma diminuição na distância física leva a maiores esforços colaborativos. Abordando este problema, traçamos um estudo etnográfico de um centro de controle ferroviário co-localizado onde as maiores organizações ferroviárias holandesas estão alojadas sob o mesmo teto. Embora a intenção da co-localização fosse melhorar a colaboração aproximando as diferentes organizações, os nossos resultados contam uma história diferente. Os empregados ferroviários desenvolveram várias práticas territoriais através das quais resistiram ao projeto, criando um espaço do centro de controle "des-locado" em vez de co-locado. Argumentamos neste artigo que tentar entender a relação entre co-locação e colaboração não se deve apenas concentrar em como esses espaços organizacionais são desenhados e planejados mas, pelo contrário, em explicar como esses espaços onde a colaboração é exigida são experimentados e praticados pelos seus funcionários.

PALAVRAS-CHAVE / Espaço organizacional, territorialidade, colaboração, co- locação, inter-organizacional.

\section{RESUMEN}

\section{THIJS WILLEMS}

t.a.h.willems@vu.nl PhD Candidate at Vrije Universiteit Amsterdam, Faculty of Social Sciences - Amsterdam, Netherlands

\footnotetext{
ALFONSVAN MARREWIJK a.h.van.marrewijk@vu.n Professor at Vrije Universiteit Amsterdam, Faculty of Social Sciences - Amsterdam Netherlands
}

El presente artículo estuda el diseño de espacios co-locados y cómo los actores organizacionales experimentan dichos espacios. Hasta ahora, la literatura sobre edificios co-locados era ambigua sobre cómo una reducción de la distancia física lleva a mayores esfuerzos colaborativos. Para abordar este problema, recurrimos a un estudio demográfico de un centro de control ferroviario co-locado en el que se localizan bajo el mismo techo los transportadores de las mayores organizaciones ferroviarias holandesas. Aunque la intención de la co-locación era mejorar la colaboración al acercar a diferentes organizaciones, nuestras conclusiones cuentan una historia diferente. Los empleados ferroviarios desarrollaron varias prácticas territoriales a través de las que se resistieron al diseño, cambiando el centro de control de co-locado a "des-plazado". En este estudio, planteamos que las tentativas de comprender la relación entre co-locación y colaboración no debería concentrarse solamente en cómo dichos espacios son diseñados y planificados, sino en explicar cómo dichos espacios donde se demanda colaboración son experimentados y usados por los empleados.

PALABRAS CLAVE I Espacio organizacional, territorialidad, colaboración, co-locación, interorganizacional. 


\section{INTRODUCTION}

Scholars interested in organizational collaboration increasingly emphasize the role of the physical and spatial distance between employees, teams, and organizations to address how collaboration is achieved (Elsbach \& Bechky, 2007; Fayard \& Weeks, 2007; McKelvey, Alm, \& Riccaboni, 2003; Wilson, O'Leary, Metiu, \& Jett, 2008). Co-location, for example, is explained as a spatial intervention through which organizations address problems associated with collaboration or the coordination of work (Okhuysen \& Bechky, 2009). It brings multiple geographically dispersed teams or organizations into closer proximity (O'Mahony \& Bechky, 2008) in one space, where workstations may be arranged with few physical barriers between different groups. However, research on the effects of co-location on collaboration has yielded mixed findings.

Some studies suggest that close proximity improves collaboration among employees. According to this literature, sharing organizational space stimulates various types of interaction. For example, knowledge is disseminated easier (Song, Berends, van der Bij, \& Weggeman, 2007); the quality of teamwork increases (Hoegl \& Proserpio, 2004); employees create a shared sense of identity (Hinds \& Mortensen, 2005); information is shared more effectively (Mark, 2002); and unplanned, spontaneous encounters are promoted (Fayard \& Weeks, 2007). However, new and often unintended consequences emerge from co-location, hindering the collaborative efforts mentioned. Co-location can create new boundaries or obstacles between employees (Song et al., 2007). Pepper (2008) shows that employees working in close physical proximity worry about distracting others, resulting in less collaboration. A recent study on a co-located office where engineering, architect, and client organizations collaborate illustrates that employees build "fortresses" within the "open" environment and use physical objects "to fence off their territory and to provide a semi-private work area" (Bektas et al., 2015, p. 159). How should we interpret these mixed, even contradictory, findings?

In this paper, we argue that research on co-location treats space-co-located offices or workspaces-as abstract and static space. Collaboration is explained as an effect of a well thought out and designed space, but neglects how space is used, perceived, or resisted. For example, corridors in hospitals are designed as passageways from $A$ to $B$, but can become important places for communication between medical staff (ledema, Long, \& Carroll, 2010). Similarly, employees can appropriate organizational spaces as meaningful places where managerial policies are resisted (Courpasson, Dany, \& Delbridge, 2017). Based on work by Lefebvre
(1991), we define space not as a fixed or given spatial setting, but as socially produced through spatial practices and perceptions. From this perspective, organizational space shapes the actions of employees, while this space is simultaneously shaped by these same actions (Hernes, Bakken, \& Olsen, 2006). Here, space is conceptualized "as practices of distance and proximity which are ordered through planning and interpreted through the ongoing experience of actors" (Taylor \& Spicer, 2007, p. 335). In other words, using Korzybski's (1933) observation that the map is not the territory it claims to represent, research on co-location emphasizes the abstract "map" of co-location-its architectural design and intentions - while neglecting the "territory" of co-location-how it is practiced and experienced (see Maréchal, Linstead, \& Munro, 2013).

This paper addresses the following question: How do territorial practices shape co-located spaces where collaboration is "demanded"? We address territorial aspects that are inherently bound with and produce co-location vis-à-vis its initial design. This enhances understanding why studies on co-location have generated mixed findings, as our perspective does not focus on collaboration as a deterministic result of designed co-located space. Rather, focusing on the effects on and experiences of employees in a spatial setting where collaboration is "demanded", we show how space emerges at the interplay between maps, territories, co-location, and dislocation. We conducted a longitudinal ethnographic study on collaborative practices in the Dutch railway system between September 2013 and November 2015. We employ data of a newly built national control center (OCCR) where seven major railway organizations have been co-located since 2010 to manage complex and large disruptions. Our findings indicate that employees in the OCCR developed several territorial practices that undermined and subverted the intentions behind the design of the co-located building. These practices illuminate the conditions under which employees collaborate, transcend territories, or resurrect boundaries.

Our paper makes three contributions. First, it addresses the call for more empirical research on the relationship between co-location and collaboration (Irving, 2016). Second, it contributes to the literature on co-location by analyzing this organizational phenomenon from an explicit spatial perspective. This provides further insights into the current debate that has yielded mixed findings (e.g., Bektas et al., 2015; Reddy et al., 2001; Song et al., 2007) by illustrating that the design of co-locations does not solely determine whether and to what degree employees of different organizations collaborate. Rather, co-located space should be understood as socially 
constructed and spatially enacted through territorial practices, and the intentions and practical orientations of employees in a co-located space shape how people work together, or not. Third, although these insights might not be novel to the literature on organizational space, we provide empirically grounded insights on the role of territoriality in how the design of spatial interventions is enacted in practice. This clarifies how designed organizational space is used, contested, or resisted.

The rest of the paper is organized as follows. In the theoretical section, we discuss the relationship between co-location and collaboration, and then explore territoriality in organizations. After the methods section, in which we reflect on the methodological issues regarding the study of space, we present our ethnographic data. We conclude the paper with a discussion, and then briefly summarize the research and elaborate our contributions.

\section{Changing collaboration by changing space}

New institutional demands can trigger the emergence of new organizational spaces (Vaujany \& Vaast, 2014), and this organizational change may be realized through spatial (re)design (Cameron, 2003; Hancock, 2006; van Marrewijk, 2009). Consequently, the relation between co-location and collaboration emerged as an academic topic (e.g., Bektas et al., 2015; McElroy \& Morrow, 2010; Irving, 2016). Notwithstanding that co-location results in a change in collaborative practices, how this change occurs and shapes collaboration remains unexplored. On the one hand, co-location promises to increase collaboration, resulting in higher performance and better quality work (Hoegl \& Proserpio, 2004). Hinds and Mortensen (2005) suggest that co-location increases a sense of shared identity and context among teams, resulting in significantly less conflict than geographically distributed counterparts. On the other hand, co-location may lead to several unintended consequences that undermine efforts to improve collaboration through spatial design (e.g., Pepper, 2008)

These ambiguous findings stem from research that over-emphasizes the design and intentions of a co-located space while neglecting the situational practices of the people inhabiting these spaces. This reflects a classical assumption in organizational practice and theory that the abstract descriptions of work-design, architecture, manuals, organizational chartscan adequately represent how work is performed (Brown \& Duguid, 1991). Thus, studies on co-location generally depart from a designed space and its intentions to improve collaboration, and then map this on an organizational reality to determine whether collaboration has changed. However, we contend that this does not do justice to the role of the practices and experiences of the organizational actors working in the newly designed space.

Co-located buildings involve a new collaborative setting between different teams, departments, or organizations. We view inter-organizational collaboration as a "hybrid" solution through which organizations attempt to tackle problems that individual entities cannot solve themselves (Gray, 1985). This relates to the notion of organizational boundaries, especially when considering that co-located buildings may need to dissolve existing boundaries between individual entities and simultaneously create new ones. Moreover, organizations can engage in the new collaborative setting while retaining diverging goals and interests (O'Mahony \& Bechky, 2008), which may lead to tensions (Star \& Griesemer, 1989). Co-location is a means to overcome these tensions by making the work of different groups visible to others (Okhuysen \& Bechky, 2009), facilitating the formal and informal coordination of activities. However, Reddy et al. (2001) claim that the practices of organizational members may remain unintelligible or opaque to others. Their study suggests that the practices of different groups shape how space is used, concluding that "although being physically co-located does help coordinate their activities, the diverse work practices of these groups prevent them from receiving the full benefits of co-location" (2001, p. 256).

As Dale and Burrell (2008, p. 27) argue, spatial design is a cultural and social practice within an existing system of power. Thus, power is enacted on a micro-level through the practices of organization members, and power relations may develop in different ways than intended through the design of the building (Kornberger \& Clegg, 2004). Therefore, co-location does not just provide organizational actors with a newly mapped, designed territory, but this territory is produced and reproduced through practices (cf. Lefebvre, 1991). Similarly, a practice approach to organizational boundaries illuminates how boundaries in co-located buildings may be blurred or reinforced in everyday organizational life (Østerlund \& Carlile, 2005). Thus, illuminating these practices may clarify co-location, which we now elaborate in the context of territoriality.

\section{The map... or the territory?}

The anthropological literature has been a rich source for our understanding of space and territories (Low \& Lawrence-Zuñiga, 2003; Rodman, 1992). Departing from Lefebvre's (1991) insights, we distinguish between two literature streams: space-as-map and 
space-as-territory. For Lefebvre, space is not a container that is "just there," but is socially produced through how it is conceived (through abstract representations), perceived (through everyday practices), and lived or imagined.

The first stream perceives space as fixed, an ethnographic local reality taken for granted, an exotic setting in which social relations are more or less fixed to territories. Corsin Jimenez (2003) calls this an objectified understanding of space with social relations having certain spatial capabilities. He criticizes this understanding by addressing problems of representation. It proposes space as a fixed category, a map with given attributes, rather than an emerging or fluid territory. Similarly, Maréchal et al. (2013) draw on Korzybski's (1933) expression that the map is not the territory it represents, illustrating that a fixed conception of space does not engage with space as it is lived and embodied by people through their material practices. In Lefebvre's (1991) words, the space-as-map perspective is a limited understanding of how space comes about, as it emphasizes how space is conceived in abstract plans or designs.

The space-as-map perspective is problematic in the context of co-location. The design of space is reified to the extent that what is mapped is equated with the territory, forgetting that such abstractions are always incomplete. That on the map is not part of the territory or of "things themselves." The map is constructed from our (incomplete) understanding of the territory, and this is nothing but the information we perceive about differences in the world (Bateson, 1987; Zundel, 2014) such as in height, or the boundary as a static line dividing separate parts. However, in the territory, boundaries between sub-systems (or co-located sub-teams) are not static, but active enactments of differences, emphasizing how these sub-systems can be both close and distant spatially, both separated and joined (Cooper, 1986).

The second stream of studies, the space-as-territory perspective, views space as socially constructed, politicized, and emerging from a specific historical and multivocal trajectory (Low \& Lawrence-Zuñiga, 2003; Rodman, 1992). From this perspective, space is produced through practices and events that are already spatial and material, rather than inscribed from an outside and abstract map (Corsin Jimenez, 2003; Maréchal et al., 2013). Explained by Lefebvre's idea of the social production of space, this perspective focuses on space beyond how it is planned by architects or managers by considering how space is perceived (practiced or used) and lived (experienced or symbolically constructed). The practices and experiences of those working in the planned space may be counter to the intentions behind its design. For example, the appropriation and reconstruction of a specific (designed) place by employees may produce a meaningful place where they can subvert managerial intentions and plans (Courpasson et al., 2017).

This relates to a phenomenological understanding of space. For instance, anthropologist Ingold (2000) sees space not in terms of how the world is designed in a representational style (the building perspective), but how it emerges through our engagement in that world (the dwelling perspective). In fact, building would be impossible without our dwelling (see also Heidegger, 1971), as "the forms people build, whether in the imagination or on the ground, arise within the current of their involved activity, in the specific relational contexts of their practical engagement with their surroundings" (Ingold, 2000, p. 186). In other words, space is not just where people are, but also involves their practical engagement with it (Corsin Jimenez, 2003)

This implies that organizational territories are flexible to the extent that actors can conform, resist, or work around spaces as designed. From this emerge questions about co-location that emphasize issues related to power: who (re)defines a territory, whose meaning prevails, who places landmarks, where are the shortcuts? Here, de Certeau's (1984) understanding of power relations is relevant, as he distinguishes between spatial strategies and tactics. A strategy involves the calculation of power relations in which subjects with power "rationally" postulate something as a place; for example, managers claiming that an office is now a co-located space where collaboration is demanded. However, referring to de Certeau's "tactics of the weak," this postulated place can be spatially manipulated or contested through actors' practices. Thus, territoriality implies that co-location as designed space can be contested. Its meaning and boundaries are open to negotiation and may materialize in different ways than intended.

In conclusion, the literature on co-location highlights the space-as-map perspective, emphasizing a space with fixed, designed capabilities. Consequently, organizational scholars reach diverging conclusions about whether and to what extent collaboration has changed as per the original intentions. The map either adequately or insufficiently represents the new organizational reality. Our paper advances this literature by arguing that the abstract representations of a space are only one aspect through which to understand co-location. Adding the space-as-territory perspective, we begin to interpret the mixed findings in the literature. This perspective considers the daily practices and experiences of employees inhabiting a co-located building where collaboration is demanded, thereby accounting for maps and territories, order and disorder, blurred and reinforced organizational boundaries, and co-location and dis-location. 


\section{METHODOLOGY}

\section{Research context}

Until 1995, the Nederlandse Spoorwegen (NS) managed the Dutch railway system. For nearly 60 years, the NS was the only organization managing the railways and all rail-related aspects (infrastructure, trains, traffic control, railway police, train mechanics, etc.). Then, under European legislation, parts of the organization were privatized, and in 2005, NS split into NS Passengers and ProRail. The commercial operator NS Passengers became responsible for railway transport, and the publicly owned ProRail for traffic control, infrastructure management, and rail allocation. The split experienced a fair share of setbacks and difficulties (Veenendaal, 2004), and a series of harsh Dutch winters in the first decade of the new millennium resulted in "black days." Control was lost of the entire railway system, stranding people for hours at stations without information. Following this, both organizations publicly blamed the other for under-performance, creating a further territorial gap between NS and ProRail. Every Dutch citizen had an opinion about the railways, ridiculing the fact that minor influences such as wet leaves and some snow had such catastrophic effects on the once-renowned railways.

On Wednesday afternoon, April 6, 2005, the computer systems in one regional traffic control center malfunctioned. This was the first of a series of incidents that culminated in disrupting the entire railway system. Until the next morning, it was impossible to ride any train to the city of Utrecht, a major hub. Internal research indicated the physical distance between the organizations and different regional control posts as the reasons for the lasting disruption. It was deemed difficult to communicate and collaborate effectively when various parties did not share a common operational plan. This initiated the development of a national control center, the OCCR. To overcome problems related to physical distance and prevent similar future disruptions, the organizations were brought in closer proximity through co-location in one control center to facilitate collective sensemaking of future disruptions (see Merkus et al., 2017).

Furthermore, the Dutch government issued statements that the organizations had to increase performance and improve collaboration. These institutional demands led to the emergence of a new organizational space through which the railway organizations attempted to claim a (renewed) sense of legitimacy (Vaujany \& Vaast, 2014). The OCCR was established and since 2010 , the most important railway organizations are co-located here in one building (see figure 1 for a simplified layout of the OCCR).
Figure 1. Layout of the OCCR

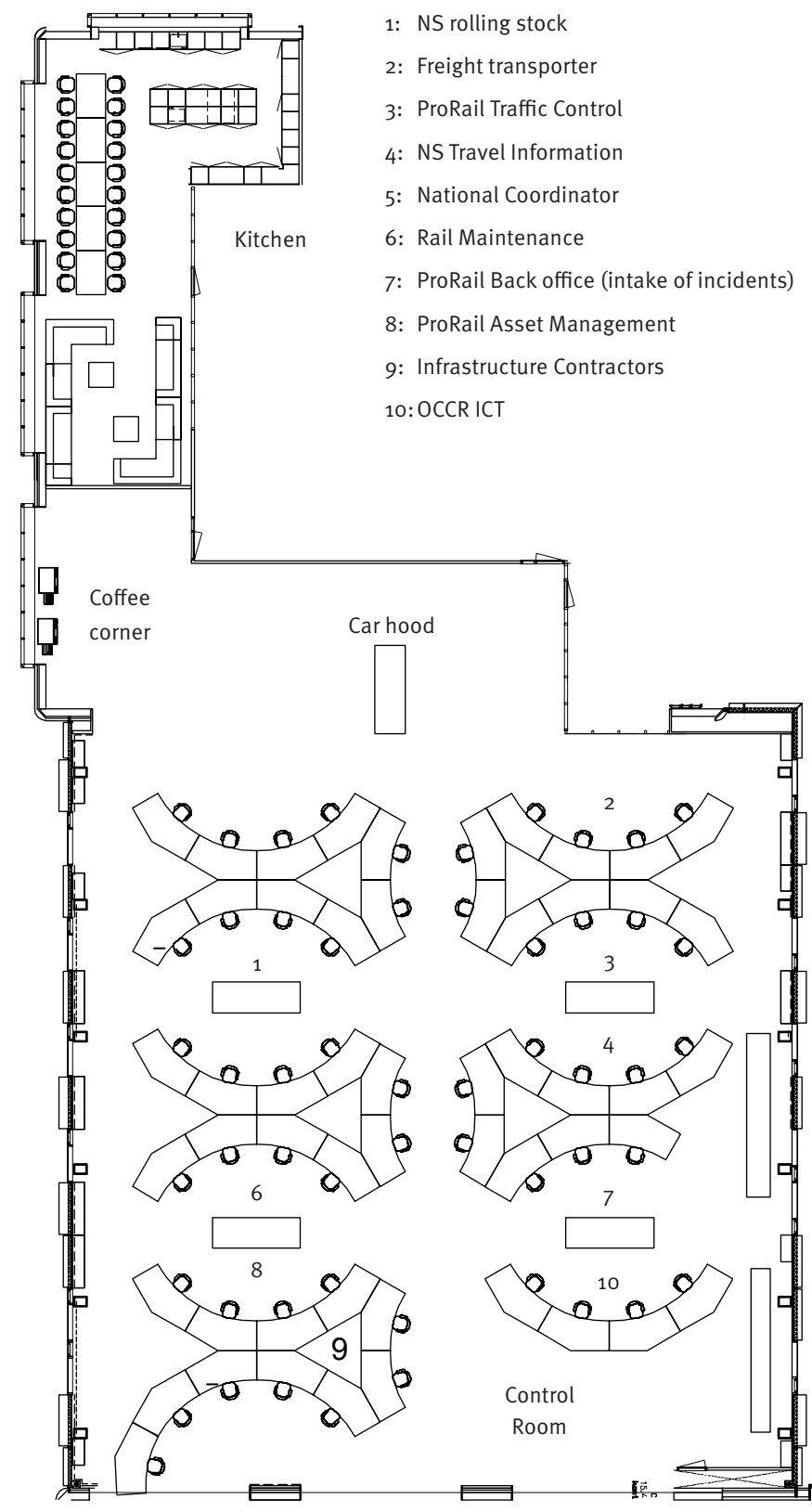

\section{Methods and analysis}

To study the OCCR, we employed a range of methods typical in ethnographic studies (Ybema, Yanow, Wels, \& Kamsteeg, 2009) to assess, observe, and understand the territorial practices through which employees challenge the co-located space. By being present in the organization for a long period, ethnographers aim to interpret and explain cultural and organizational phenomena (Pettigrew, 1990) to understand employees' daily activities (Yanow \& Schwartz-Shea, 2006). The OCCR research was part of a larger 
study on collaboration in the Dutch railway system conducted between September 2013 and November 2015.

In this study, several interpretive research methods were used to collect data on the OCCR, including participant observation, observation, interviews, and document analysis. Although participation was limited because of the highly specialized work of coordinators at the OCCR, from a spatial perspective, the ethnographer could participate, because by being there, he dwelled in and experienced the co-located building. By obtaining a "feel" for the organizational space and its materials, the ethnographer tried to become aware of his own embodied experiences through auto-ethnographic reflection (van Marrewijk, 2011).

The ethnographer conducted 80 field visits to the OCCR, each lasting between two to eight hours. For these visits, he followed coordinators during their shifts, attended their meetings, joined them for lunch, and observed their practices. He followed coordinators from the different organizations located in the OCCR, and was there during normal operations as well as during disruptions and incidents to observe both the exceptional and mundane (Ybema et al., 2009). While ethnographic reflections highlighted the experience (of the ethnographer) of the OCCR, the observations of coordinators focused on their use of the space. He also conducted 13 interviews to obtain additional information on the OCCR. Of these, five were with managers and external consultants who initiated and developed the OCCR from idea to construction, and eight were with coordinators working in the co-located space. The interviews with consultants and managers focused on the design and intentions of the OCCR, while the interviews with coordinators pinpointed their experience and use of space. Finally, organizational documents on plans and the implementation of the OCCR were analyzed to clarify the design of the building.

During the fieldwork, we based our analysis on the autoethnographic reflections of how the researcher experienced the space. The rest of the research was conducted in an iterative inductive style (O'Reilly, 2005), whereby the analysis guided further observations and vice versa. We started exploring the notion of co-location from various theoretical explanations such as inter-organizational collaboration, territoriality, and aspects of identity and power, which were further probed in the interviews. Eventually, we deemed it best to stay close to the physicality of the OCCR as a co-location, which is inherently spatial, and analyzed this spatial setting through the notion of territoriality. By reading and re-reading our data, we discovered that different spaces in the OCCR were used in different ways. We analyzed these in terms of territoriality, finding the spaces of the kitchen and control room most interesting. Focusing on the data, we started understanding the discrepancies between spaces as designed and their use and experience in practice. From this, the practices of preserving, enacting, and situationally using territorial boundaries emerged, as illustrated in the empirical section.

\section{FINDINGS: CO-LOCATION OR 'DIS- LOCATION'?}

Maréchal et al. state that the creation of new organizational forms such as the OCCR implicate "the emergence of new territorial assemblages" (2013, p. 202). Thus, we can expect that the co-location of distinct organizations produces questions of power and identity. We demonstrate how these issues were not verbally negotiated, but spatially enacted by OCCR employees in defining the territories in the new building. One example is offered by an OCCR project manager, who reflects on how the transition from design to actual use occurred when the building was officially opened and "occupied" by the first shift of employees:

After more than three years of designing and building, the OCCR was finished, a brand new high-tech control center, the showpiece of the rail sector. The night of the move, I stood on the balcony with a colleague...The first people arrived, and the National Coordinator, the figurehead of the OCCR, took a large yellow pencil sharpener from his bag. Without hesitating, he screwed it down onto the untouched shining desks. We could not actually hear it, but I still imagine how the plywood of the desktop cracked: In our eyes, a brute baptism of the workplace. From that moment, the OCCR was not ours anymore, but in the hands of the employees (interview: project manager).

\section{The kitchen: Do not enter}

The consultants and project managers responsible for the design of the OCCR were aware that people usually bond by sharing food:

We started a kitchen committee... We needed a common space for informal interaction between people... We tried to be a good example. On the night of completion [of the OCCR], I personally 
cooked six big pots of mash. We wanted to show: People, cook for each other! (interview: project manager).

It seems universally accepted that cooking, eating, and sharing food is both a necessity of human existence and a way through which people bond. Anthropological examples on the role and meaning of cooking and eating in specific cultures abound, ranging from cooking as a "language" through which society translates its structures (Levi-Strauss, 1997) to cookbooks as "artifacts of culture in the making" (Appadurai, 1988, p. 22). Food and food-related topics are sources through which anthropologists study the constructed nature of diverse societal processes (for a thorough review, see Mintz \& Bois, 2002).

Railway operations are performed in 24/7 shifts including breaks for breakfast, lunch, and dinner. An OCCR coordinator explains how food was an important aspect of shifts when he worked in a regional (not co-located) control center. You ordered or cooked food "with the whole crew," and it "really belonged to the work": Collective meals, parties, spontaneous after-work drinks ("drinking with the boys"), and self-organized holidays with colleagues. Stories about the past abound, illustrating the nature of the "family rails." Through this nostalgic talk, they emphasized the collective identity of their past and exemplified the lack of a collective identity in the current co-located building. According to a coordinator, there had been two attempts to organize a barbeque with all OCCR employees, but both failed because of a meager turnout. There was one exception. "Traffic Information" sometimes arranged informal breakfasts on Sunday mornings. However, this breakfast reinforced boundaries, as it was not an invitation for the other organizations to join: "Sometimes, only if I am lucky, they fry me an egg as well," smirked a coordinator.

\section{Preserving existing territorial boundaries}

The kitchen in the OCCR was anything but a place to cook. Here, few engaged in real conversation and fewer stayed to enjoy their meal. The following excerpt from the ethnographic field notes describes a typical day in the OCCR kitchen around dinnertime:

The television, which is always on, broadcasts the opening ceremony of the Olympic winter games in Sochi. The couches, where no one sits, are empty. The chairs, never occupied, are turned upside down on the tables. The fluorescent light shines bright, but a faint mood prevails. The kitchen block looks uniform. All cabinets are sterile white and lack a handgrip. From the outside, I cannot discern cupboards from dishwashers. At the far end are several refrigerators in the same design as the other cabinets. Upon closer inspection, I see nametags on each. NS, ProRail Traffic Control, ProRail Asset Management, ICT, Back Office, Freight Transporter. Each column has its own fridge. In front of the microwaves stand five men in a row, waiting for their food to be finished. They are silent, except for the occasional smothered "hello" or "have a good shift" whenever someone joins or leaves the row. A microwave beeps and a man steps out of the row to get his plate. With a fork, he squashes the amorphous lump of spaghetti into a model, while on the television, the fireworks and bombastic music of the opening ceremony climax. He leaves the kitchen to enjoy dinner behind his desk (observation during fieldwork: February 7, 2014).

The "emptiness" of the kitchen can be described using Stein's famous expression, “There is no there there” (1937, p. 289), an abandoned place of which most meaning has been deprived. Using Auge's (1995) terminology, we can argue that the kitchen is a non-place. A non-place is "a space which cannot be defined as relational, or historical, or concerned with identity” (1995, pp. 77-78). However, from a territoriality perspective, the kitchen is a space full of meaning. The OCCR as a co-located space is designed to reflect the demands for improved collaboration between railway organizations, forcing OCCR employees to collaborate to a certain extent. One usually goes to the kitchen when on a break or off duty; therefore, it is also an informal space not under the scrutiny of managerial control. Thus, the kitchen is an "unmanaged" space. The OCCR as a map, a representational concept that intends to stimulate inter-organizational collaboration, also fostered unintended practices through which employees sought ways to preserve existing territorial boundaries.

First, the kitchen was collectively constructed as a place to be avoided or tread lightly in. Evidencing the "un-kitchenly" atmosphere (bright lights, no talking, chairs turned upside down on tables), it was not an inviting place in which to eat, alone or together. There was a myth that after the OCCR was installed, the kitchen was used by people who disagreed with "forced" collaboration to vent their aggression, resulting in broken kitchen objects. Although no one seemed to remember this when asked 
directly, someone reflected that this myth implicitly constructed the kitchen as taboo: “Apparently, it has become a no-man'sland, because the social pressure of your own tribe is so high that...you should not show your face in the kitchen" (interview: OCCR consultant).

Second, fridges were marked per individual organization. Before the OCCR started its operations, employees had already labeled the fridges with stickers of the organizations' names. For a former OCCR consultant, the banal labels on the fridges could be traced back to the splitting of NS and ProRail in the beginning of the century: "All conversations about the OCCR were poisoned by discussions between NS and ProRail about who would become the boss of the building...If this is what managers communicate to the people below, the result is fridges with stickers" (interview: consultant OCCR). A project manager adds that labeling the fridges was a way for employees to maintain their individual identities: "We knew we needed several fridges, because we had to facilitate a large group of people. However, this resulted in fridges earmarked per 'blood type"” (interview: project manager). Stories about the fridges were implicit or ironic, building on the myth of the kitchen as a no-man's land where territories were preserved. When shadowing one National Coordinator, he insisted the researcher put his dinner in their fridge, as "our fridge is better than the others" (informal conversation).

In sum, the kitchen was a place where OCCR employees could preserve already existing territorial boundaries through socio-material practices. Following de Certeau (1984), these tactics of the weak are ways through which people manipulate a dominating strategy spatially rather than verbally. The managers of the project team also realized they could not do anything about these tactics: "We cannot force people to put their rolls in another fridge" (interview: project manager).

\section{The control room: Traitors, friends, and foes}

The control room is the heart of the OCCR. Here, the largest railway organizations are represented, from which the operation of the Dutch train traffic is managed 24/7. Smaller disruptions are still managed from the regional posts. In the OCCR, coordinators aim to reduce the impact of disruptions and anticipate and prevent larger disruptions (e.g., when extreme weather is expected). The control room is designed as an open space of $1,000 \mathrm{~m}^{2}$, accommodating around 100 workstations. The floor level is equal, as differences in height could be interpreted as hierarchical differences. Each workstation is uniformly designed to allow flexible positioning and promote mingling of employees of the individual columns. In rows of four, the desks are arranged in a semi-circular formation called "bananas" to optimize the lines of sight necessary for easy communication and collaboration between organizations. However, spatial use in the control room differed from how it was intended. The individual organizations usually sat together in one group. Moreover, although the desks were designed in a semi-circular shape to disclose the space to every individual (figure 2a), teams could also enclose themselves from the rest by slightly repositioning their chairs (figure $2 b$ ), thereby implicitly reinforcing territorial boundaries.

Figure 2a. Intended sightlines: Organizational focus

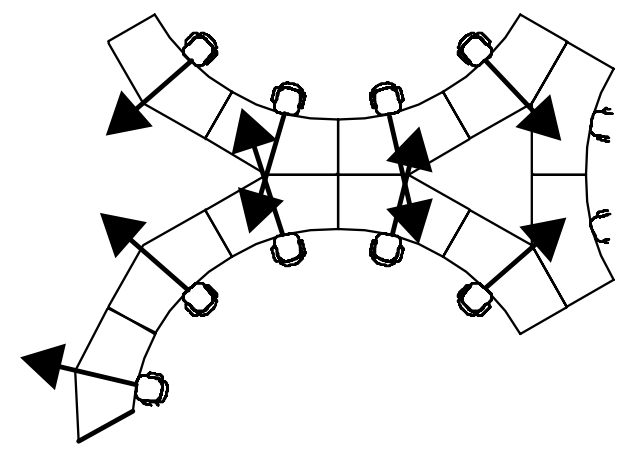

Figure $2 b$. Changing sightlines: Team focus

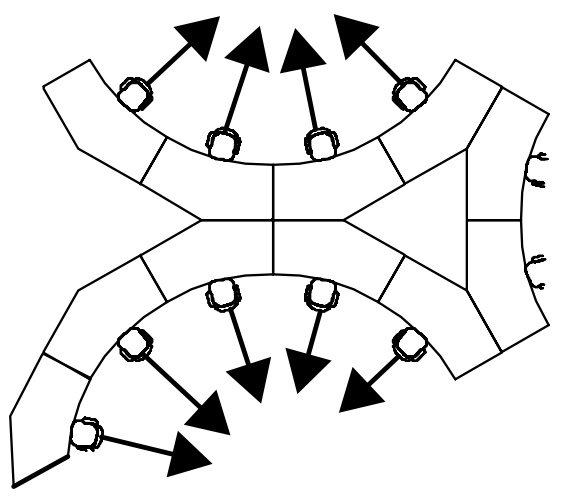

\section{Enacting territorial boundaries}

In the control room, territories were enacted through indirect and implicit verbal and spatial communication. The work of one of the organizations, which was concerned with the official registration of incidents, was mostly performed by phone, requiring concentration and silence. Sometimes, these employees would let the others know their disregard of noise in the control room by releasing a long and loud "shhhhhh!" One coordinator 
explained this was because they were once located in a separate office without other teams or organizations. He remembered this as "a little paradise secluded from everybody else" (informal conversation). The hushing was a way to communicate to others to keep quiet without insulting anyone specific.

Sometimes, coordinators intentionally raised their voices to implicitly communicate a message to others:

A coordinator complains to the ethnographer about a colleague from another organization, sitting 2 meters from us. He had tried to arrange something without informing her. She raises her voice: "This guy [winking at him without looking] believes he is the boss. Right now though, he has nothing to decide on this matter; it has to go through us." Without paying attention to him, she wants her remarks to be heard (observation during fieldwork: February 10, 2014).

By claiming ownership over particular resources according to certain procedures ("this belongs to us"), territorial differences were enacted, rather than dissolved. This indirect messaging occurred regularly, and we interpreted it as ways through which employees enacted territorial boundaries to cope with being co-located with those with different goals or working styles.

Although no visible boundaries were evident in the control room (e.g., objects hindering lines of sight) and there were no visible signs of differences in the design of the workstations, boundaries between the organizations (or borders between territories) were most sensible here:

Today, I will shadow Margret [NS]. Since I cannot find her immediately, I chat with Linda [ProRail], whom I already shadowed a few times. We are discussing her upcoming holidays when Margret joins: "Hey, let us go to my place okay?" I know it sounds strange, but I feel like a traitor. Linda does not seem to mind, but I am aware that today, I will visit "the Other." The whole day I feel the separation between Linda and myself. It is an invisible border between us. Invisible, but clearly there (observation during fieldwork: January 20, 2014).

Not only the researcher "felt" these divisions. The employees of the control room were also aware of the boundaries separating the individual organizations, and this sense of territoriality was spatially enacted in different ways. During a workshop by one of the columns, a coordinator explained what his colleague did when someone "from the other side of the aisle" came to him regarding an issue: "He does not look up, but says 'No! No! No!' synchronized with the rhythm of the footsteps of the other" (informal conversation). The others chuckle and share their nicknames for others.

Often, when a coordinator from one organization would walk to another to discuss a potentially difficult topic, both went to great lengths to symbolically rematerialize the non-existent barriers between them:

From a distance, Nate walks towards Jesse. With firm steps and eyes focused on Jesse, almost like a cowboy in a Wild West movie, he walks towards him in a straight line. It looks like "the Walk" I often observed. As if one makes a passage to another place, to an enemy you need to address. The conversation could open with, "I come in peace my brother." When Nate arrives, Jesse pretends to not notice him. Nate pauses for a second, and then without hesitation, knocks on Jesse's table. “Knock, knock," Nate says loudly. Jesse turns his chair towards Nate, but keeps his eyes on me: "I believe I have a customer," he says with acted surprise (observation during fieldwork: February 26, 2015).

These practices reinforced the differences between the territories, which co-location aimed to dissolve to soothe communication and collaboration. Through the Walk, proximity was constructed as distant rather than close, and not noticing someone at the table illustrated denial rather than acceptance. Knocking on an imaginary door resurrected the walls the OCCR tried to demolish, demonstrating closure, rather than openness, and welcoming the other as "a customer" reinforced differences in identity and power relations.

\section{Situational use of territorial boundaries}

Despite the enactment of territorial boundaries described above, the coordinators were mostly able to collaborate or agree on certain matters. This required that the boundaries between the territories were blurred to some degree. Thus, as the following section shows, boundaries were not fixed, but situationally constructed. Again, Nate and Jesse are a good example: 
Nate needs information on the prognosis of an incident, but Jesse nonchalantly tells him he does not feel like making the necessary calls right now. Nate reacts resolutely: "I do not agree. You cannot easily get away with this and I am disgruntled." This could imply the end of the conversation or beginning of a discussion. However, the conversation continues on a different topic. Earlier that week, a mechanic had forgotten to bring his lance (a safety tool to prevent trains from entering tracks under repair) to an incident, causing a delay of an extra 20 minutes and 2 cancelled trains. Both Jesse and Nate are astonished by the incident, and together accuse the mechanic of a sloppy job. The cold conversation between the two seems to thaw, and Jesse promises to chase the prognosis, which was the reason Nate came to Jesse (observation during fieldwork: February 26, 2015).

People in the OCCR seemed capable of forming and breaking bonds with others relatively easily. In fact, the Other could shift within seconds from the "enemy" to a "friend." Situationally using the territorial boundaries seemed a way through which coordinators could cope with various competing interests. Thus, when certain practical orientations demanded collaboration, territorial boundaries became temporarily blurred.

When a larger disruption unexpectedly hit the railway system, coordinators formed a collective bond against a nonOCCR actor (e.g., a regional post, the disruption itself, news about bad railway performance, a winter storm preventing train traffic). On these occasions, a coordinator could ask for a consultation "on the car hood." The car hood is a large white cabinet just off the main floor of the control room, approximately 1,5 meters high so that people could easily stand around it. One coordinator explained that the car hood referred to the idea that sometimes, rapid problem solving was needed: "You get out of the car, put a map on the hood, and gather around it to quickly find your way again" (informal conversation). Around the space of the car hood and with a common enemy in mind, discussions or disagreements between coordinators were non-existent. In this spatial setting, collective decisions were made relatively easily. It acted as a neutral land through which coordinators could temporarily lift territorial boundaries. Thus, employees constructed a new space when facing a collective and practical problem, indicating how territories were contingent on situational demands. Through the situational use of spatial settings and flexible bonding of coordinators, territorial boundaries were lifted, accounting for the fact that despite many differences, coordinators could still agree on certain matters.

Here, three spatial practices of dis-location were identified related to the construction of territories: the preservation of existing territorial boundaries, enacting new territorial boundaries, and the situational use of territorial boundaries. Exhibit 1 provides an overview.

\section{Exhibit 1. Territorial practices and effects}

\begin{tabular}{|c|c|c|}
\hline Practice & Examples & What does it do? \\
\hline $\begin{array}{l}\text { Preserving } \\
\text { existing territorial } \\
\text { boundaries }\end{array}$ & $\begin{array}{l}\text { - The kitchen as } \\
\text { "taboo" } \\
\text { - Labeling } \\
\text { fridges }\end{array}$ & $\begin{array}{l}\text { Constructing space } \\
\text { as "taboo" or "no- } \\
\text { man's land" to } \\
\text { resist co-location; } \\
\text { employees preserve } \\
\text { existing territorial } \\
\text { boundaries } \\
\text { and identities } \\
\text { of individual } \\
\text { organizations. }\end{array}$ \\
\hline $\begin{array}{l}\text { Enacting new } \\
\text { territorial } \\
\text { boundaries }\end{array}$ & $\begin{array}{l}\text { - Indirect } \\
\text { messaging } \\
\text { (hushing, } \\
\text { raising one's } \\
\text { voice) } \\
\text { - Reinforcing } \\
\text { boundaries } \\
\text { (the Walk, } \\
\text { "knock knock") }\end{array}$ & $\begin{array}{l}\text { Making boundaries } \\
\text { between } \\
\text { the different } \\
\text { organizations } \\
\text { visible in a co- } \\
\text { located space } \\
\text { where such } \\
\text { boundaries are } \\
\text { physically non- } \\
\text { existent. }\end{array}$ \\
\hline $\begin{array}{l}\text { Situational use } \\
\text { of territorial } \\
\text { boundaries }\end{array}$ & 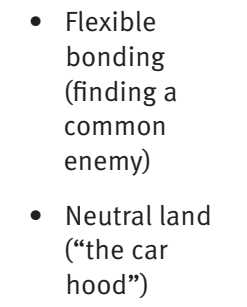 & $\begin{array}{l}\text { Temporarily } \\
\text { lifting territorial } \\
\text { boundaries to reach } \\
\text { agreement and } \\
\text { collaborate in a co- } \\
\text { located space. }\end{array}$ \\
\hline
\end{tabular}

\section{DISCUSSION AND CONCLUSIONS}

This study explored the relation between co-location and interorganizational collaboration in the OCCR by analyzing the concept of territoriality. The findings show that although the OCCR was spatially designed to improve collaboration between Dutch railway organizations, employees developed several territorial practices that subverted the intentions of the co-located space. In the kitchen, existing territorial boundaries between the individual 
organizations were preserved, transforming the kitchen into a nonplace (Auge, 1995). The kitchen, designed as a space to stimulate informal collaboration through cooking and sharing food, became a taboo when the OCCR was initiated. The earmarked fridges, reminiscent of a past when no collaboration was demanded by such close proximity, demonstrate how the kitchen became a place where OCCR employees spatially resisted the managerial intentions of the co-located building (cf. Courpasson et al., 2017).

In the control room, the designers of the OCCR expended great efforts to abolish these territorial boundaries through an egalitarian workspace with uniform workstations to promote the flexible mingling of employees. However, new territorial boundaries were enacted through spatial practices such as the Walk or knocking on someone's invisible door. This is a reminder of what Wilson et al. (2008) define as a spatial paradox: colleagues can physically be in close proximity while perceiving the distance to be quite far. Thus, while the plan for the co-located building was to decrease distance, the practices of OCCR employees produced a space where new territorial boundaries were resurrected, increasing the perceived distance between organizations.

These territorial boundaries appeared situational. When collaboration was not managerially but practically demanded (e.g., during major incidents), OCCR employees lifted the territorial boundaries by creating a common enemy. This is aligned to Irving (2016), who views collaborative spaces as scaffolds, where an important factor regarding the collaboration of co-located colleagues is the practical intention of employees. However, our analysis indicates that even in cases when collaboration was practically perceived as necessary, OCCR coordinators did not use the spaces designed to facilitate collaboration. Instead, they created new spaces such as the car hood, where territorial boundaries could be lifted, albeit temporarily. This suggests that scholars interested in collaboration from a spatial perspective can emphasize the situational construction of territorial and/or professional boundaries (see ledema et al., 2010).

Through the practices discussed above, employees found ways to carve their territories, fostering what co-location aims to diminish. These findings are in line with Maréchal et al. (2013, p. 202), who state that the creation of new organizational forms imply "the emergence of new territorial assemblages." The preservation of existing and enactment of new territorial boundaries created the OCCR as dis-location, rather than co-location.

The distinction between space-as-map and space-asterritory further clarifies the discrepancies between the OCCR as designed co-location and practices of dis-location. As argued in this paper, the space-as-map perspective is incomplete and provides a too static understanding of co-location. Included on the map are abstractions derived from our understanding of the territory (cf. Bateson, 1987). Thus, our findings extend studies that define collaboration as an effect or outcome of co-location. Offering an alternative perspective that considers what happens in the territory, we show how co-located buildings emerge from a recursive process (Hernes et al., 2006). Co-located spaces shape how people collaborate, but not in a deterministic way. These spaces are shaped by the practices and experiences of the people "inhabiting" that space. Space-as-territory emphasizes how space as designed may be contested. Territorial practices provide further insights into the political dimension of space (Kornberger \& Clegg, 2004), showing how spaces and practices are inscribed with power (Dale \& Burrell, 2008).

This alternative perspective makes three contributions. First, we clarified the complex relationships between spatial design and spatial use in the context of collaboration in co-located spaces. This addresses the call for more empirical research by scholars interested in collaboration in co-located spaces (e.g., Bektas et al., 2015; Irving, 2016). Second, our findings show that territoriality opens new vistas from which to study the relation between co-location and inter-organizational collaboration, as it introduces dis-location. This understanding may extend the literature beyond the current impasse, where research on co-location has yielded ambiguous findings (e.g., Hoegl \& Proserpio, 2004; Mark, 2002; Pepper, 2008), as it challenges the assumption that the design of space determines whether and to what degree people collaborate. Here, the space-as-map and space-as-territory distinction is interesting, as it provides a more dynamic understanding of the relationship between spatial design and use; thus, it may help interpret the mixed findings. However, we caution that spatial practices of dis-location are not necessarily negative or dysfunctional. In contrast, they may be functional for employees situated in a co-located office, as they help to negotiate sameness and difference. Furthermore, this suggests that future research on co-location could address how questions of identity shape collaboration in such buildings.

Finally, this paper contributes to the literature on how organizational space is enacted in and through practices (e.g., Hernes et al., 2006; van Marrewijk \& Yanow, 2010; Vaujany \& Mitev, 2013), claiming territoriality as an insightful concept to study how these spaces emerge, develop, institutionalize, or change over time. Future studies can unveil the development of new organizational spaces over time (e.g., Vaujany \& Vaast, 2014) by focusing on how new territories emerge or old ones are breached. This development is not expected to happen without contestation, and indeed, the notion of territoriality could reveal more about the political and spatial dimensions of new spaces. 
Similarly, changing forms of organizational spaces produce new forms of organizational control (Dale, 2005), and territoriality could provide the means to study how these forms of control are spatially and materially resisted and the effects thereof.

\section{REFERENCES}

Appadurai, A. (1988). How to make a national cuisine: Cookbooks in contemporary India. Comparative Studies in Society and History, 30(1), 3-24.

Auge, M. (1995). Non-Places: Introduction to an Anthropology of Supermodernity. London, UK: Verso.

Bateson, G. (1987). Steps to an Ecology of Mind: Collected Essays in Anthropology, Psychiatry, Evolution, and Epistemology (2nd ed.). London, UK: Jason Aronson Inc.

Bektas, E., Lauche, K., \& Wamelink, H. (2015). Knowledge sharing in megaprojects: A case study of a co-location approach. In A. van Marrewijk (Ed.), Inside Megaprojects: Understanding Cultural Practices in Project Management (pp. 137-174). Copenhagen, Denmark: CBS Press.

Brown, J. S., \& Duguid, P. (1991). Organizational learning and communities-of-practice: Toward a unified view of working, learning, and innovation. Organization Science, 2 (1), 40-57.

Cameron, K. S. (2003). Organizational transformation through architecture and design: A project with Frank Gehry. Journal of Management Inquiry, 12 (1), 88-92. doi:10.1177/1056492602250522

Cooper, R. (1986). Organization/Disorganization. Social Science Information, 25(2), 299-335. doi:10.1177/053901886025002001

Corsin Jimenez, A. (2003). On space as a capacity. Journal of the Royal Anthropological Institute, 9(1), 137-153. doi:10.1111/1467-9655.to1-1-00008

Courpasson, D., Dany, F., \& Delbridge, R. (2017). Politics of place: The meaningfulness of resisting places. Human Relations, 70 (2), 237-259. doi:10.1177/0018726716641748

Dale, K. (2005). Building a social materiality: Spatial and embodied politics in organizational control. Organization, 12(5), 649-678. doi: $10.1177 / 1350508405055940$

Dale, K., \& Burrell, G. (2008). The Spaces of Organisation and the Organisation of Space: Power, Identity and Materiality at Work. Hampshire, UK: Palgrave Macmillan.

de Certeau, M. (1984). The Practice of Everyday Life. Berkeley, USA: trans. Steven Rendall, University of California Press.

Elsbach, K. D., \& Bechky, B. A. (2007). It's more than a desk: Working smarter through leveraged office design. California Management Review, 49(2), 80-102. doi:10.2307/41166384

Fayard, A-L., \& Weeks, J. (2007). Photocopiers and water-coolers: The affordances of informal interaction. Organization Studies, 28(5), 605634. doi:10.1177/0170840606068310

Gray, B. (1985). Conditions facilitating interorganizational collaboration. Human Relations, 38(10), 911-936.doi:10.1177/001872678503801001

Hancock, P. (2006). The spatial and temporal mediation of social change. Journal of Organizational Change Management, 19(5), 619639. doi:10.1108/09534810610686706
Heidegger, M. (1971). Building Dwelling Thinking. In Poetry, Language, Thought (pp. 141-160). New York, USA: Harper \& Row.

Hernes, T., Bakken, T., \& Olsen, P. I. (2006). Spaces as process: Developing a recursive perspective on organisational space. In $\mathrm{S}$. Clegg \& M. Kornberger (Eds.), Space, Organizations and Management Theory (pp. 44-63). Copenhagen, Denmark: CBS Press.

Hinds, P. J., \& Mortensen, M. (2005). Understanding conflict in geographically distributed teams: The moderating effects of shared identity, shared context, and spontaneous communication. Organization Science, 16(3), 290-307. doi:10.1287/orsc.1050.0122

Hoegl, M., \& Proserpio, L. (2004). Team member proximity and teamwork in innovative projects. Research Policy, 33(8), 1153-1165. doi:10.1016/j.respol.2004.06.005

ledema, R., Long, D., \& Carroll, K. (2010). Corridor communication, spatial design and patient safety: enacting and managing complexities. In A. van Marrewijk \& D. Yanow (Eds.), Organizational Spaces. Rematerializing the Workaday World (pp. 41-57). Cheltenham, UK: Edward Elgar Publishing Limited.

Ingold, T. (2000). The Perception of the Environment. London, UK: Routledge.

Irving, G. L. (2016). Collaboration in Open-Plan Offices. University of Queensland Business School.

Kornberger, M., \& Clegg, S. (2004). Bringing space back in: Organizing the generative building. Organization Studies, 25(7), 1095-1114. doi:10.1177/0170840604046312

Korzybski, A. (1933). Science and Sanity: An Introduction to NonAristotelian Systems and General Semantics. (5th ed.). Brooklyn, New York, USA: Institute of general semantics.

Lefebvre, H. (1991). The Production of Space. Oxford, UK: Blackwell.

Levi-Strauss, C. (1997). The culinary triangle. In C. Counihan \& P. Van Esterik (Eds.), Food and Culture: A Reader (pp. 28-35). New York, USA: Routledge.

Low, S. M., \& Lawrence-Zuñiga, D. (2003). Anthropology of Space and Place: Locating Culture. Malden, USA: John Wiley \& Sons.

Maréchal, G., Linstead, S., \& Munro, I. (2013). The territorial organization: History, divergence and possibilities. Culture and Organization, 19(3), 185-208. doi:10.1080/14759551.2013.812703

Mark, G. (2002). Extreme collaboration. Communications of the ACM, 45(6), 89-93. doi:10.1145/508448.508453

McKelvey, M., Alm, H., \& Riccaboni, M. (2003). Does co-location matter for formal knowledge collaboration in the Swedish biotechnologypharmaceutical sector? Research Policy, 32(3), 483-501. doi:10.1016/ So048-7333(02)00020-3

Merkus, S., Willems, T., Schipper, D., van Marrewijk, A., Koppenjan, J., Veenswijk, M., \& Bakker, H. (2017). A storm is coming? Collective sensemaking and ambiguity in an inter-organizational team managing railway system disruptions. Journal of Change Management, 17(3), 228-248. doi:10.1080/14697017.2016.1219380

Mintz, S. W., \& Bois, C. M. Du. (2002). The anthropology of food and eating. Annual Review of Anthropology, 31, 99-119. doi:10.1146/ annurev.anthro.32.032702.131011 
O’Mahony, S., \& Bechky, B. A. (2008). Boundary organizations: Enabling collaboration among unexpected allies. Administrative Science Quarterly, 53(3), 422-459. doi:10.2189/asqu.53.3.422

O'Reilly, K. (2005). Ethnographic Methods. New York, USA: Routledge.

Okhuysen, G. A., \& Bechky, B. A. (2009). Coordination in organizations: An integrative perspective. The Academy of Management Annals, 3(1), 463-502. doi:10.1080/19416520903047533

Østerlund, C., \& Carlile, P. (2005). Relations in practice: Sorting through practice theories on knowledge sharing in complex organizations. The Information Society: An International Journal, 21(2), 91-107. doi:10.1080/01972240590925294

Pepper, G. L. (2008). The physical organization as equivocal message. Journal of Applied Communication Research, 36(3), 318-338. doi:10.1080/00909880802104882

Pettigrew, A. M. (1990). Longitudinal field research on change: Theory and practice. Organization Science, 1(3), 267-292.

Reddy, M. C., Dourish, P., \& Pratt, W. (2001). Coordinating heterogeneous work: Information and representation in medical care. In W. Prinz, M. Jarke, Y. Rogers, K. Schmidt, \& V. Wulf (Eds.), Proceedings of the Seventh European Conference on Computer-Supported Cooperative Work (pp. 239-258). Dordrecht: Springer Netherlands.

Rodman, M. (1992). Empowering place: Multilocality and multivocality. American Anthropologist, 94(3), 640-656.

Song, M., Berends, H., van der Bij, H., \& Weggeman, M. (2007). The effect of IT and co-location on knowledge dissemination. Journal of Product Innovation Management, 24(1), 52-68. doi:10.1111/j.15405885.2006.00232.x

Star, S. L., \& Griesemer, J. R. (1989). Institutional ecology, "translations" and boundary objects: Amateurs and professionals in Berkeley's Museum of Vertebrate Zoology, 1907-39. Social Studies of Science, 19(3), 387-420. doi:10.1177/030631289019003001

Stein, G. (1937). Everybody’s Autobiography. New York, USA: Random House.
Taylor, S., \& Spicer, A. (2007). Time for space: A narrative review of research on organizational spaces. International Journal of Management Reviews, 9(4), 325-346. doi:10.1111/j.14682370.2007.00214.X

van Marrewijk, A. (2009). Corporate headquarters as physical embodiments of organisational change. Journal of Organizational Change Management, 22(3), 290-306. doi:10.1108/09534810910951078

van Marrewijk, A. (2011). Aesthetic experiences of designed organisational space. International Journal of Work Organisation and Emotion, 4(1), 61-77. doi:10.1504/ijwoe.2011.041531

van Marrewijk, A., \& Yanow, D. (2010). Organizational spaces: Rematerializing the workaday world. Cheltenham, UK: Edward Elgar Publishing Limited.

Vaujany, F. X. de, \& Mitev, N. (2013). Materiality and Space: Organizations, Artefacts and Practices. Hampshire, UK: Palgrave Macmillan.

Vaujany, F. X. de, \& Vaast, E. (2014). If these walls could talk: The mutual construction of organizational space and legitimacy. Organization Science, 25(3), 713-731. doi:10.1287/orsc.2013.0858

Wilson, J. M., O’Leary, M. B., Metiu, A., \& Jett, Q. R. (2008). Perceived proximity in virtual work: Explaining the paradox of far-but-close. Organization Studies, 29(7), 979-1002. doi:10.1177/0170840607083105

Yanow, D., \& Schwartz-Shea, P. (2006). Interpretation and Method: Empirical Research Methods and the Interpretive Turn. Armonk, USA: Sharpe.

Ybema, S., Yanow, D., Wels, H., \& Kamsteeg, F. (2009). Organizational Ethnography: Studying the Complexity of Everyday Life. London, UK: Sage Publications.

Zundel, M. (2014). Chapter 23: Gregory Bateson (1904-1980). In J. Helin, T. Hernes, D. Hjorth, \& R. Holt (Eds.), The Oxford Handbook of Process Philosophy and Organization Studies (pp. 364-379). OUP Oxford. 